\title{
INHIBITION OF COPPER CORROSION IN CHLORIDE SOLUTION BY CAFFEINE ISOLATED FROM BLACK TEA
}

\author{
Senka Gudic ${ }^{1 *}$, Emeka E. Oguzie ${ }^{2}$, Ani Radonić ${ }^{3}$, Ladislav Vrsalović ${ }^{1}$, \\ Ivana Smoljko ${ }^{1}$, Maja Kliškić ${ }^{1}$ \\ ${ }^{1}$ Department of Electrochemistry and Materials Protection, Faculty of Chemistry and Technology, \\ Split, Croatia \\ ${ }^{2}$ Electrochemistry and Materials Science Research Laboratory, Department of Chemistry, \\ Federal University of Technology Owerri, Owerri, Nigeria \\ ${ }^{3}$ Department of Organic Chemistry, Faculty of Chemistry and Technology, Split, Croatia \\ senka@ktf-split.hr
}

Caffeine (1,3,7-trimethylxanthine) was isolated from black tea and characterized using different physical methods (determination of melting point, thin layer chromatography, FTIR spectroscopy and UV spectrophotometry). The corrosion inhibition performance of the caffeine isolate on copper corrosion in neutral $0.5 \mathrm{~mol} \mathrm{l}^{-1} \mathrm{NaCl}$ solution was investigated using potentiodynamic polarization and electrochemical impedance spectroscopy measurements. The obtained results show that caffeine effectively inhibited the corrosion reaction in the chloride solution with an inhibition efficiency of up to $\approx 92 \%$. Furthermore, caffeine was found to function essentially as a cathodic inhibitor by adsorption on the copper surface according to the Langmuir adsorption isotherm. The adsorption free energy of $\approx-37 \mathrm{~kJ} \mathrm{~mol}^{-1}$ indicates strong adsorption of the caffeine on the metal surface. Quantum chemical computations and molecular dynamics simulations were adapted to understudy the adsorption of a single caffeine molecule as well as a polymeric cluster of caffeine molecules on a model $\mathrm{Cu}$ surface at a molecular level and was consistent with the experimental findings.

Keywords: adsorption isotherm; caffeine; copper; corrosion; inhibition

\section{ИНХИБИЦИЈА НА БАКАРНА КОРОЗИЈА ВО ХЛОРИДЕН РАСТВОР НА КОФЕИН ИЗОЛИРАН ОД ЦРН ЧАЈ}

Кофеин (1,3,7-триметилксантин) изолиран од црн чај е карактеризиран со употреба на физички методи (температура на топење, тенкослојна хроматографија, FTIR спектроскопија и UV спектрометрија). Способноста за инхибиција на корозијата на изолираниот екстракт врз бакарот е испитувана во неутрален $0,5 \mathrm{~mol} \mathrm{l}^{-1} \mathrm{NaCl}$ раствор со примена на потенциодинамичка поларизација и на електрохемиска импедансна спектроскопија. Добиените резултати покажуваат дека кофеинот ефикасно ја инхибира реакцијата на корозија во хлориден раствор, при што ефикасноста на инхибицијата изнесува и до $\approx 92 \%$. Покрај тоа, утврдено е дека кофеинот во основа служи како катоден инхибитор со атсорпција на бакарната површина согласно атсорпционата изотерма на Langmuir. Вредноста на атсорпционата слободна енергија од $\approx-37 \mathrm{~kJ} \mathrm{~mol}^{-1}$ укажува силна атсорпција на кофеинот врз металната површина. Беа применети квантнохемиски пресметки и молекуларнодинамички симулации за подобро разбирање на атсорпцијата на единична молекула на кофеинот, како и полимерен кластер на кофеински молекули на модел на бакарната површина на молекулско ниво и се покажа дека се во согласност со експерименталните резултати.

Клучни зборови: атсорпциона изотерма; кофеин; бакар; корозија; инхибиција 


\section{INTRODUCTION}

Copper and copper alloys possess certain superior properties making them useful for a wide variety of applications including; production of wires, sheets and pipes, computer and microelectronics, etc. Copper is also used extensively as a structural material in cooling and heating systems, power plants, oil refineries, and automobiles. However, copper reacts easily with oxygen in oxygencontaining environments to form an oxide layer [1]. This surface oxide has a duplex structure made up of an inner cuprous oxide layer and an outer cupric oxide layer, depending on the electrode potential $[2,3]$. Because of limited protection offered by copper oxides, the metal is susceptible to different forms of corrosion, such as uniform and pitting corrosion, induced by corrosive species like chloride, sulphate, hydroxide and nitrate ions [4, 5].

One of the most important methods for the corrosion protection of copper is the use of organic inhibitors; however, widespread application of many commercial organic inhibitors has been hindered by cost and toxicity considerations. Accordingly, several studies have focussed on identifying effective, inexpensive and nontoxic alternatives. Some of such investigations have assessed the corrosion-inhibiting properties of natural products of plant origin, which have been found to generally exhibit good inhibition efficiencies [6-13]. This area of research is significant because plant products are inexpensive, readily available and renewable sources of environmentally acceptable materials. This paper focuses on copper corrosion inhibition in $\mathrm{NaCl}$ using caffeine (1,3,7-trimethylxanthine) isolated from black tea.

Black tea is usually obtained from the Assamese plant (Camellia sinensis subsp. assamica) and is additionally fermented, hence more oxidized and stronger in flavour than green or white tea [14, 15]. Caffeine (Figure 1) belongs to a class of methylxanthine alkaloids present in coffee, cocoa beans, cola nuts and tea leaves [16]. Caffeine is extensively used in the production of non-alcoholic beverages and pharmaceuticals because of its stimulating and muscle relaxing properties [17]. Accordingly, the effect of caffeine on human health and behaviour has been relatively well documented [18, 19]. Studies on the adsorption and protective effect of commercially available caffeine on the corrosion of various metals and alloys in different aggressive solutions have shown that this organic compound has a considerable corrosion-inhibiting potential and, thus, deserves more in-depth inves- tigation [20-23]. Again, in line with current efforts at promoting the utilization of biomass resources for the reasons mentioned earlier, it is also necessary to similarly assess the corrosion-inhibiting efficacy of caffeine isolated from biomass extracts.<smiles>Cn1c(=O)c2c(ncn2C)n(C)c1=O</smiles>

Fig. 1. Structural formula of caffeine

Interestingly, the present study does not only experimentally evaluate the corrosion inhibition performance of caffeine isolated directly from black tea, but it also attempts to further obtain in depth mechanistic insights into the corrosion inhibition and adsorption behaviour of caffeine by performing theoretical computations in the framework of the density functional theory (DFT). This approach involves analysis of the molecular electronic structures of the molecule as well as the nature of the molecule-metal interaction via molecular dynamics. Molecular dynamics simulation of metal-inhibitor interactions considers adsorption of a single caffeine molecule as well as a polymeric cluster of caffeine molecules on a $\mathrm{Cu}(110)$ slab.

\section{EXPERIMENTAL}

\subsection{Materials preparation}

The working electrode was made from copper (99.98\% purity). Prior to each measurement, the electrode surface was mechanically treated by grinding and polishing with different grades of emery paper, degreased in ethanol and rinsed in bidistilled water. The exposed geometric area was 0.2 $\mathrm{cm}^{2}$. A new electrode surface was used for each run. The test solution was $0.5 \mathrm{~mol} \mathrm{l}^{-1} \mathrm{NaCl}$, prepared from analytical grade reagent and bi-distilled water.

\subsection{Isolation of caffeine}

Caffeine was isolated from black tea (Franck, Zagreb, Croatia). An amount of $30 \mathrm{~g}$ of black tea was placed in an $800 \mathrm{ml}$ beaker with $7.5 \mathrm{~g} \mathrm{Na}_{2} \mathrm{CO}_{3}$ to which distilled water $(400 \mathrm{ml})$ was subsequently added. The mixture was boiled for 20 minutes and filtered using a Buchner funnel. The water filtrate 
was extracted with dichloromethane three times $(1 \times 100 \mathrm{ml}$ and $2 \times 50 \mathrm{ml})$. The water and organic solvent layer were separated by centrifuging. The dichloromethane extract was transferred into an Erlenmeyer flask and dried using $\mathrm{Na}_{2} \mathrm{SO}_{4}$. The dried extract was further concentrated using a vacuum evaporator and then cooled in a refrigerator in order to initiate the crystallization of caffeine. The caffeine crystals were separated from solution by filtration using a Buchner funnel. About $0.4332 \mathrm{~g}$ of caffeine was isolated from the $30 \mathrm{~g}$ of initial biomass.

Different physical methods were employed to characterize the crystalline caffeine obtained from black tea, including determination of melting point, thin layer chromatography (TLC), UV and FTIR spectroscopy. The melting temperature was determined by differential scanning calorimetry (DSC) using a Differential Scanning Calorimeter (Mettler Toledo 823E). The sample $(\approx 10 \mathrm{mg}$ ) was hermetically sealed in an aluminium pan and heated at a constant rate over a temperature range of $25-300{ }^{\circ} \mathrm{C}$. An inert atmosphere was maintained by purging with nitrogen gas. Thin layer chromatography was performed on a commercial aluminium plate $20 \times 20 \mathrm{~cm}$ coated with a $0.2-\mathrm{mm}$ thin layer of silica gel and the crystalline caffeine using a $9.5: 0.5, \mathrm{v}: \mathrm{v}$ mixture of chloroform and ethanol as mobile phase and visualized under a UV-lamp $(\lambda=254 \mathrm{~nm})$. The UV-absorption spectrum of the extracted crystalline caffeine was obtained using a UV/VIS spectrophotometer (PerkinElmer Lambda EZ 201). Quartz cuvettes (Hellma) with an optical path length of $1 \mathrm{~cm}$ and a volume of $1.5 \mathrm{ml}$ were used. Ethanol and water were used as solvent for the caffeine. The Fourier transform infrared (FTIR) spectrum of isolated caffeine was recorded on a Perkin Elmer FTIR spectrophotometer (Spectrum One) over a wave number range of $4000-650 \mathrm{~cm}^{-1}$ with a resolution of $4 \mathrm{~cm}^{-1}$. Samples were prepared as $\mathrm{KBr}$ pellet.

\subsection{Corrosion measurements}

Electrochemical experiments were conducted in a three-electrode cell using a potentiostat (PAR M273A) in combination with a lock-in amplifier (PAR M5210). A platinum sheet was used as counter electrode and a saturated calomel electrode (SCE) as reference electrode. The latter was connected via a Luggin's capillary.

Measurements were performed in aerated and stagnant chloride solutions at $25 \pm 1{ }^{\circ} \mathrm{C}$. Caffeine was added in concentrations from $1 \times 10^{-5}$ to $1 \times 10^{-3} \mathrm{~mol} \mathrm{l}^{-1}$. The electrode was allowed to stabilize for $60 \mathrm{~min}$ before the measurements started. Po- tentiodynamic current-potential curves were obtained by changing the electrode potential from 250 to $+250 \mathrm{mV}$ versus the open circuit potential with a scan rate of $0.2 \mathrm{mV} \mathrm{s}^{-1}$. Impedance measurements were carried out at the open circuit potential. The a.c. amplitude was $10 \mathrm{mV}$, and the frequency range studied varied from $50 \mathrm{kHz}$ to $30 \mathrm{mHz}$.

\subsection{Computational details}

All theoretical computations were performed within the framework of DFT using the Materials Studio; MS Modelling 4.0 software (Accelrys Inc.). The electronic structures of caffeine and the $\mathrm{Cu}$ surface were modelled by means of the DFT electronic structure program $\mathrm{DMol}^{3}$ using a Mulliken population analysis as well as a Hirshfeld numerical integration procedure [24, 25]. Electronic parameters for the simulation include restricted spin polarization using the DNP basis set and the Perdew Wang (PW) local correlation density functional.

Molecular dynamics (MD) simulation of the non-covalent interaction between a single caffeine molecule as well as a polymeric cluster of caffeine molecules (constructed using the Polymer Builder module) and the $\mathrm{Cu}$ surface was performed using Forcite quench molecular dynamics to sample many different low energy configurations and identify the low energy minima [26, 27]. Calculations were carried out, using the COMPASS force field and the Smart algorithm, in a simulation box $30 \times 25 \times 29 \AA$ with periodic boundary conditions to model a representative part of the interface, devoid of arbitrary boundary effects. The box was comprised of a $\mathrm{Cu}$ slab cleaved along the (110) plane and a vacuum layer of $20 \AA$ height. The geometry of the bottom layer of the slab was constrained to the bulk positions whereas other degrees of freedom were relaxed before optimizing the $\mathrm{Cu}(110)$ surface, which was subsequently enlarged into a $10 \times 8$ supercell. Inhibitor molecules were adsorbed on one side of the slab. The temperature was fixed at $303 \mathrm{~K}$, with an NVE (microcanonical) ensemble, with a time step of $1 \mathrm{fs}$ and simulation time of 5 ps. The system was quenched every 250 steps. Optimized structures of caffeine molecules and the $\mathrm{Cu}$ surface were used for the simulation.

\section{RESULTS AND DISCUSSION}

\subsection{Characterization of caffeine}

The analysis of the crystalline material isolated from black tea using the DSC, TLC, UV and 
FTIR spectroscopy confirmed the presence of high purity caffeine.

The thermal behaviour of caffeine is presented in the DSC thermogram shown in Figure 2 and reveals a sharp endothermic peak at $235{ }^{\circ} \mathrm{C}$, which is in accordance with published data [16]. As DSC is considered to be a very accurate method for melting point determination, the data in Figure 2 is positive evidence of isolation of high purity caffeine.

For the thin layer chromatography experiment, the plate, after evaporation of the solvent, was visualized under UV light (with $\lambda=254 \mathrm{~nm}$ ) and revealed one brown spot. The $R_{\mathrm{f}}$ value of the isolated caffeine was found to be 0.63 , which is consistent with the published data, and is very close to the $R_{\mathrm{f}}$ value of the reference sample of commercial caffeine (0.64) [16]. The characteristic UV absorption spectrum and absorption maximum $\left(\lambda_{\max }\right)$ were also employed in identification of the isolated compound. The $\lambda_{\max }$ was $272.9 \mathrm{~nm}$ for the isolate in water as solvent and $272.6 \mathrm{~nm}$ in ethanol as solvent, which is similar to the values reported in the literature for caffeine $[16,28,29]$. The $\lambda_{\max }$ values of the isolate also coincide with the values of the reference samples (commercial caffeine).

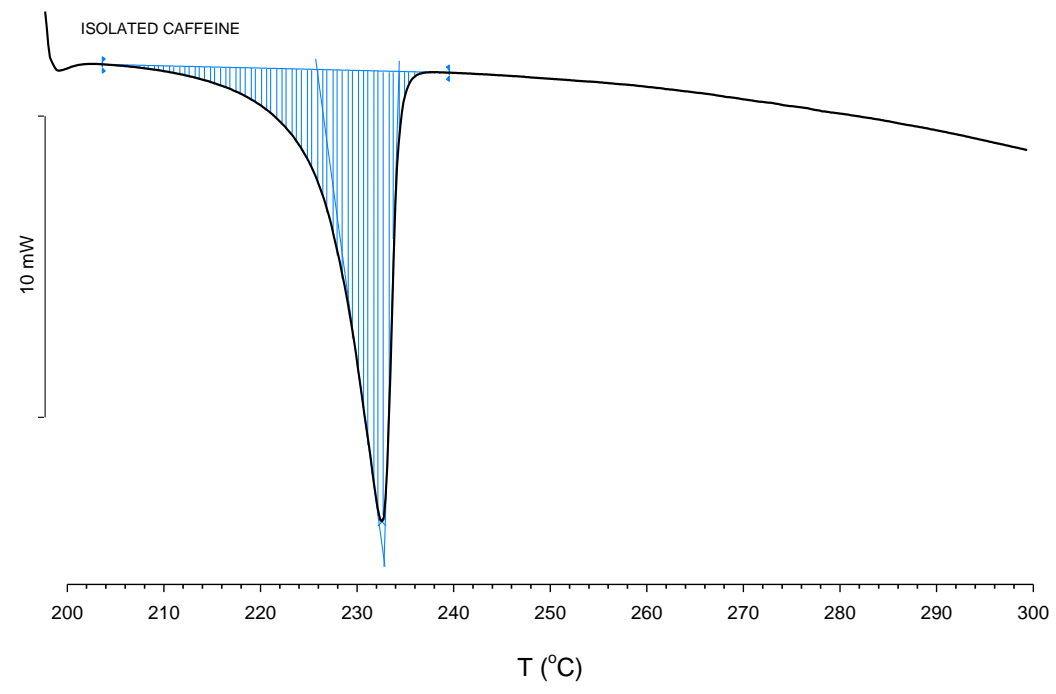

Fig. 2. DSC curve of caffeine isolated from black tea

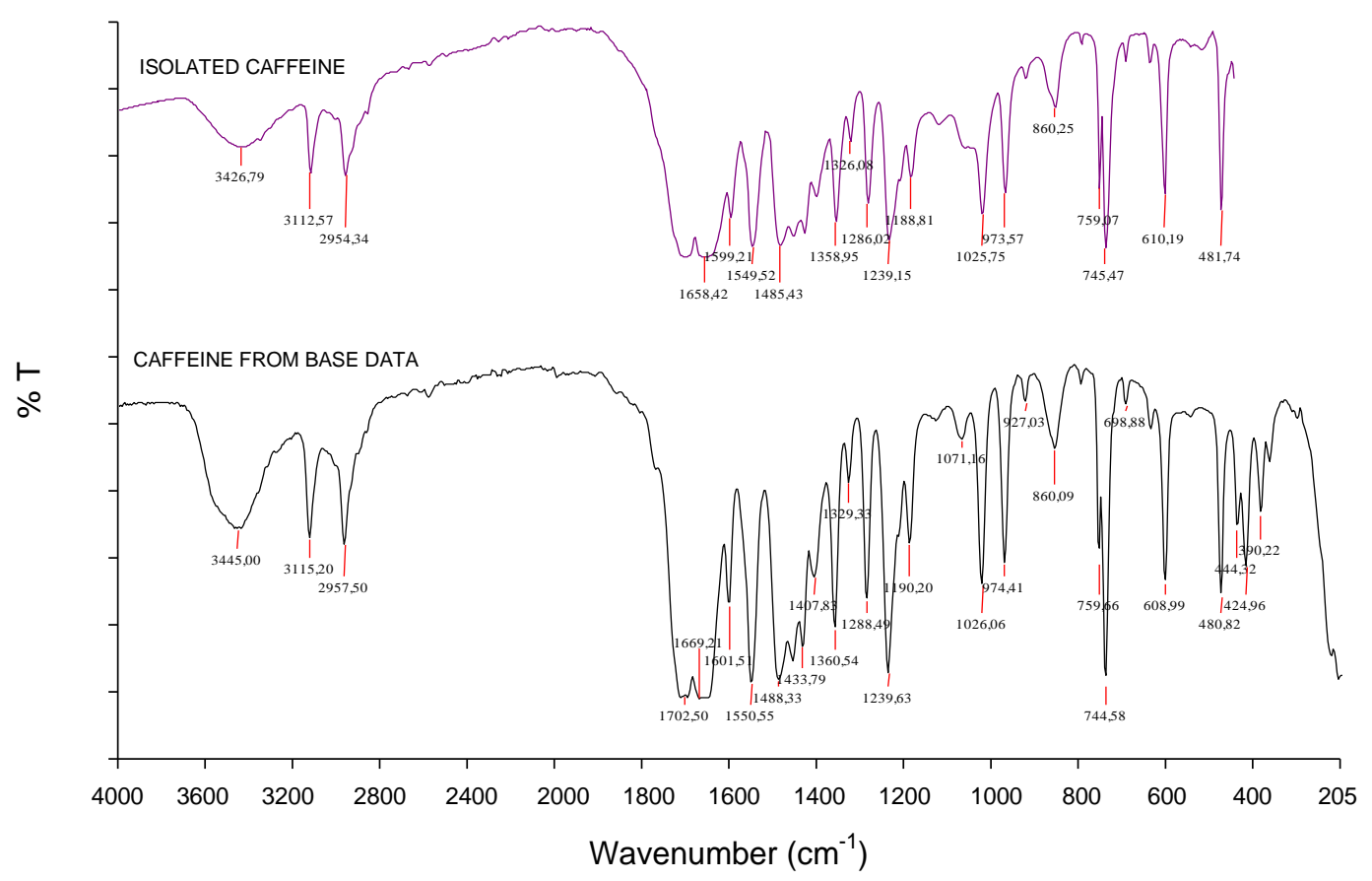

Fig. 3. FTIR spectra of caffeine isolated from black tea and caffeine from base data of instrument 
The FTIR spectrum of the isolated caffeine showed comparable absorption bands with that of standard caffeine (Figure 3). The bands due to aromatic $\mathrm{C}-\mathrm{H}$ stretching appear at $3112 \mathrm{~cm}^{-1}$ (correspond to $\mathrm{C}-\mathrm{H}$ ) and $2954 \mathrm{~cm}^{-1}$ (corresponds to $\mathrm{C}=\mathrm{H})$. The $\mathrm{C}=\mathrm{O}$ stretching frequency appears at $1701 \mathrm{~cm}^{-1}$. The band at $1658 \mathrm{~cm}^{-1}$ is due to $\mathrm{C}=\mathrm{C}$ stretching. The band at $1239 \mathrm{~cm}^{-1}$ is attributed to $\mathrm{C}-\mathrm{N}$, while that at $1549 \mathrm{~cm}^{-1}$ is assigned to $\mathrm{C}=\mathrm{N}$. The obtained results are in accordance with previously published data $[16,20]$. The match between the spectra of the isolated caffeine and spectra from the base data was $97.2 \%$. The above findings all point towards the purity of the caffeine as isolated from black tea.

\subsection{Polarization measurements}

Figure 4 shows the polarization curves obtained for copper in $0.5 \mathrm{~mol} \mathrm{l}^{-1} \mathrm{NaCl}$ solution without and with the addition of caffeine in different concentrations (from $1 \times 10^{-5}$ to $1 \times 10^{-3} \mathrm{~mol} \mathrm{l}^{-1}$ ). The anodic polarization curve for copper in $\mathrm{NaCl}$ solution displayed three distinct regions: a Tafel region at lower overpotentials extending to the peak current density at $-60 \mathrm{mV}$, a region of decreasing currents until a minimum is reached, and the region of second increase in current above $-20 \mathrm{mV}$.

The mechanism of copper dissolution in chloride media has been extensively studied, and it has been found to be quite sensitive to chloride concentration, independent of the solution $\mathrm{pH}$ [3036]. At potentials close to the open circuit potential and at $\mathrm{Cl}^{-}$ion concentrations lower than $1 \mathrm{~mol} \mathrm{l}^{-1}$, the copper dissolution process proceeds via a twostep reaction mechanism. In the first step, a copper atom is ionised under the influence of a $\mathrm{Cl}^{-}$ion, yielding slightly soluble adsorbed $\mathrm{CuCl}$ species at the electrode, according to:

$$
\mathrm{Cu}+\mathrm{Cl}^{-} \leftrightarrow \mathrm{CuCl}+\mathrm{e}^{-}
$$

The $\mathrm{CuCl}$ has poor adhesion to the copper surface and in the presence of $\mathrm{Cl}^{-}$ions is further transformed into the soluble cuprous chloride complex, $\mathrm{CuCl}_{2}^{-}$[32]:

$$
\mathrm{CuCl}+\mathrm{Cl}^{-} \rightarrow \mathrm{CuCl}_{2}^{-}
$$

$\mathrm{At} \mathrm{Cl}^{-}$ion concentrations higher than $1 \mathrm{~mol} \mathrm{l}^{-1}$, cuprous complexes such as $\mathrm{CuCl}_{3}{ }^{2-}$ and $\mathrm{CuCl}_{4}{ }^{3-}$ start to appear [33].

At potentials close to the corrosion potential, the anodic reaction is under mixed charge transfer and mass transport control kinetics, where the mass transport limiting step is diffusion of soluble $\mathrm{CuCl}_{2}{ }^{-}$species from the electrode surface into bulk solution (which results in an apparent anodic Tafel slope of $60 \mathrm{mV} /$ decade). According to thermodynamic analysis [36], if the $\mathrm{CuCl}_{2}^{-}$concentration in the outer Helmholtz plane exceeds the solubility equilibrium between $\mathrm{CuCl}$ and $\mathrm{CuCl}_{2}^{-}$species, copper will favourably oxidize to $\mathrm{CuCl}$ via Equation 1. Moreover, more insoluble $\mathrm{CuCl}$ begins to precipitate on the copper surface forming a $\mathrm{CuCl}$ salt film, which leads to passivation of the copper surface and a decrease in the current density. The anodic peak is, therefore, attributed to the formation of $\mathrm{CuCl}$ film [33]. At higher potentials, $\mathrm{Cu}$ is probably further oxidized to $\mathrm{Cu}^{2+}$, which causes the current to increase again.

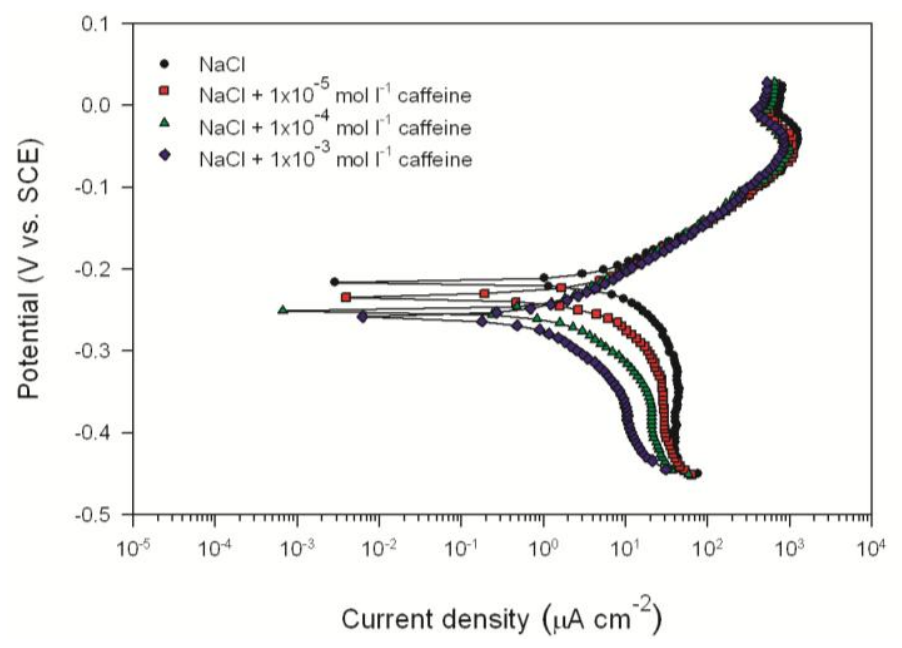

Fig. 4. Potentiodynamic polarization curves for $\mathrm{Cu}$ in $0.5 \mathrm{~mol}^{-1} \mathrm{NaCl}$ solution in the absence and presence of caffeine 
The cathodic polarization curve for copper in $\mathrm{NaCl}$ solution displays the current plateau in potential range from $\approx-280$ to $\approx-430 \mathrm{mV}$, which may be attributed to the diffusion controlled reduction reaction of dissolved oxygen:

$$
\mathrm{O}_{2}+2 \mathrm{H}_{2} \mathrm{O}+4 \mathrm{e}^{-} \rightarrow 4 \mathrm{OH}^{-}
$$

Addition of caffeine to the $\mathrm{NaCl}$ solution did not notably affect the anodic reaction but remarkably decreased the cathodic current density, as well as shifted the corrosion potential towards more negative values. These effects were significantly enhanced upon increasing the caffeine concentration. The corrosion potential $\left(E_{\text {corr }}\right)$ and corrosion current density $\left(i_{\text {corr }}\right)$ values derived from the polarization curves are listed in Table 1.

Table 1

Corrosion parameters for $\mathrm{Cu}$ in $0.5 \mathrm{~mol}^{-1} \mathrm{NaCl}$ solution in the absence and in the presence of caffeine

\begin{tabular}{cccc}
\hline \hline $\begin{array}{c}c_{\text {caffeine }} \\
\left(\mathrm{mol} \mathrm{1}^{-1}\right)\end{array}$ & $\begin{array}{c}E_{\text {corr }} \\
(\mathrm{mV})\end{array}$ & $\begin{array}{c}i_{\text {corr }} \\
\left(\mu \mathrm{A} \mathrm{cm}^{-2}\right)\end{array}$ & $E I_{\mathrm{P}} \%$ \\
\hline 0 & -224.7 & 10.78 & \\
$1 \times 10^{-5}$ & -232.1 & 5.34 & 50.46 \\
$5 \times 10^{-5}$ & -244.7 & 4.20 & 61.04 \\
$1 \times 10^{-4}$ & -252.8 & 2.39 & 77.83 \\
$5 \times 10^{-4}$ & -258.2 & 1.52 & 85.90 \\
$1 \times 10^{-3}$ & -262.3 & 0.95 & 91.19 \\
\hline \hline
\end{tabular}

The values of $i_{\text {corr }}$ decreased mainly due to the corrosion-inhibiting effect of caffeine and the negative shift in $E_{\text {corr }}$ upon introduction of caffeine means that the compound functions mainly by decreasing the kinetics of the cathodic reaction. Since the transfer of oxygen from the bulk solution to the copper/solution interface will strongly affect the rate of oxygen reduction, it can be inferred that an adsorbed layer of caffeine retards the transfer of $\mathrm{O}_{2}$ to the cathodic sites of the $\mathrm{Cu}$ surface. This indicates that caffeine functions essentially as a cathodic inhibitor of $\mathrm{Cu}$ corrosion in the chloride environment.

Table 1 also lists the values of the inhibition efficiency $\left(I E_{\mathrm{P}} \%\right)$, determined from the corrosion current density using the equation:

$$
I E_{\mathrm{P}} \%=\frac{i_{\text {corr }}-\left(i_{\text {corr }}\right)_{\text {inh }}}{i_{\text {corr }}} \times 100,
$$

where $i_{\text {corr }}$ and $\left(i_{\text {corr }}\right)_{\text {inh }}$ are corrosion current densities without and with inhibitor, respectively. The inhibition efficiency increased with caffeine concentration and the optimum value of $\approx 91 \%$ was obtained with $10^{-3} \mathrm{~mol}^{-1}$ caffeine.

\subsection{Impedance measurements}

Impedance measurements were undertaken in order to obtain physical insight into the processes occurring at the copper/solution phase boundary. Figure 5 shows Bode plots (logarithm of impedance, $Z$, and phase angle respectively $v s$. logarithm of frequency, $f$ ) for the $\mathrm{Cu}$ electrode in $0.5 \mathrm{~mol} \mathrm{l}^{-1} \mathrm{NaCl}$ solution in the absence and presence of caffeine. At high frequencies $(f>1 \mathrm{kHz})$, the impedance response is dominated by the electrolyte resistance. In the medium frequency region, the linear $\log |Z| v s . \log f$ relationship with a slope close to -1 and a phase angle of $\approx-70^{\circ}$ reflect the capacitive behaviour of the system. At low frequency, the phase angle $\left(\approx-40^{\circ}\right)$ and slope of the $\log |Z| v s . \log f(-0.5)$ point towards the presence of a slow diffusion process. It can be seen that the overall impedance of system increases with caffeine concentration, which indicates that the electrode surface gets more protection.

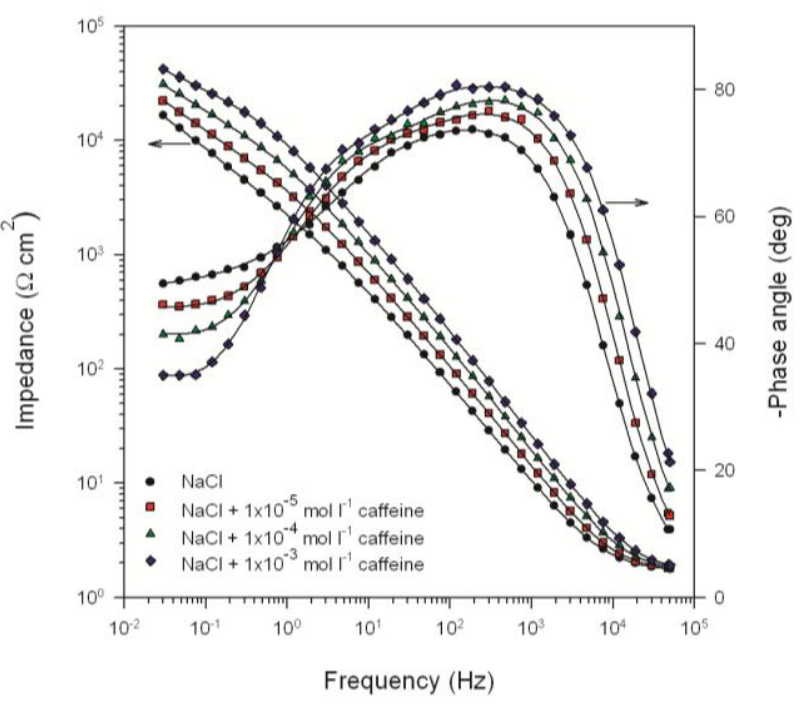

Fig. 5. Bode plots for $\mathrm{Cu}$ in $0.5 \mathrm{~mol} \mathrm{l}^{-1} \mathrm{NaCl}$ solution in the absence and presence of caffeine

The appearance of more than one time constant in the impedance spectra reflects the diversity of the interfacial phenomena in the system under investigation. The equivalent circuit proposed to fit the experimental data is shown in Figure 6 and consists of an electrolyte resistance $R_{\mathrm{el}}\left(\approx 5 \Omega \mathrm{cm}^{2}\right)$ connected with two time constants. The first time constant observed in the high frequency region 
results from the fast charge transfer process in the metal dissolution reaction. In this case, $R_{1}$ represents the charge transfer resistance, and $Q_{1}$ represents the constant phase element and replaces the capacitance of the electrical double layer. To account for the surface layer and diffusion process in the low frequency region, additional equivalent circuit parameters were introduced such as $R_{2}$ for the surface layer resistance, $Q_{2}$ for constant phase element of the surface layer $\left(Q_{2}\right.$ replaces the capacitance of surface layer) and a Warburg impedance $W$ for the diffusion process.

As can be seen, the constant phase elements replace the capacitive elements in the equivalent circuit. In many cases, the CPE is introduced to account for deviations associated with depression of capacitive loops. The impedance of the CPE, $Z_{\mathrm{CPE}}$, is described by [37]:

$$
Z_{\mathrm{CPE}}=\left[Q(j \omega)^{n}\right]^{-1}
$$

with $-1 \leq n \leq 1, j=\sqrt{ }-1$ and $\omega=2 \pi f$, while $Q$ is a frequency-independent constant, being defined as pure capacitance for $n=1$, resistance for $n=0$, inductance for $n=-1$. Diffusion processes are characterized by the value of $n=0.5$.

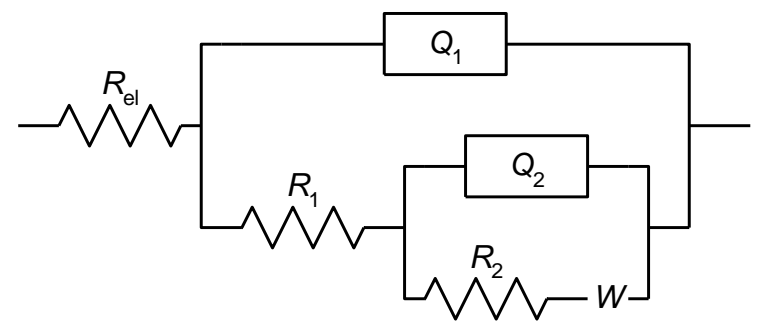

Fig. 6. Proposed equivalent circuit for modelling the impedance response of $\mathrm{Cu}$ in $0.5 \mathrm{~mol} \mathrm{l}^{-1} \mathrm{NaCl}$ solution in the absence and presence of caffeine
The calculated equivalent circuit parameters for $\mathrm{Cu}$ in chloride solution containing different concentrations of caffeine are presented in Table 2. The results obtained indicate that an increase in caffeine concentration leads to a corresponding increase of charge transfer resistance $\left(R_{1}\right)$ and surface layer resistance $\left(R_{2}\right)$, while the capacitance of the double layer $\left(Q_{1}\right)$, capacitance of the surface layer $\left(Q_{2}\right)$ and the diffusion element $(W)$ decrease. This direction of change is attributed to the increase of protective properties of the adsorbed layer on the electrode surface.

The decreasing trend in $Q_{1}$ and $Q_{2}$ values going from the uninhibited to inhibited solution and with increasing caffeine concentration provide direct experimental evidence that caffeine is actually adsorbed on the $\mathrm{Cu}$ surface and displaces the water molecule and other ions originally adsorbed on the metal surface. The evolution correlates with the observed improvement of the quality of the inhibitor film, corresponding to improved charge transfer resistance. The values of $n_{2}$ associated with $Q_{2}$ are found in the 0.71-0.78 interval revealing that the adsorbed inhibitor film is partially heterogeneous. On the other hand, the different values of $n_{2}$ are due to the modification of the chemical composition of the adsorbed film in combination with its thickness, as suggested by the $R_{2}$ values. Furthermore, according to the plate capacitor model, the surface film capacity, $C$, is inversely proportional to its thickness, $d$ (according to $C=\varepsilon_{0} \varepsilon / d ; \varepsilon_{0}$ is the permittivity of vacuum; and $\varepsilon$ the relative permittivity of the film). Hence, the reduction of $Q_{2}$ with the increase of inhibitor concentration matches the corresponding increase in the thickness of the surface layer, which additionally corresponds to an enhancement in the protective properties of the surface layer.

Table 2

Impedance parameters for the $\mathrm{Cu}$ in $0.5 \mathrm{~mol} \mathrm{l}^{-1} \mathrm{NaCl}$ solution in the absence and in the presence of caffeine

\begin{tabular}{ccccccccc}
\hline $\begin{array}{c}c_{\text {caffeine }} \\
\left(\mathrm{mol}^{-1}\right)\end{array}$ & $\begin{array}{c}Q_{1} \times 10^{6} \\
\left(\Omega^{-1} \mathrm{~s}^{\mathrm{n}} \mathrm{cm}^{-2}\right)\end{array}$ & $n_{1}$ & $\begin{array}{c}R_{1} \\
\left(\mathrm{k} \Omega \mathrm{cm}^{2}\right)\end{array}$ & $\begin{array}{c}Q_{2} \times 10^{6} \\
\left(\Omega^{-1} \mathrm{~s}^{\mathrm{n}} \mathrm{cm}^{-2}\right)\end{array}$ & $n_{2}$ & $\begin{array}{c}R_{2} \\
\left(\mathrm{k} \Omega \mathrm{cm}^{2}\right)\end{array}$ & $\begin{array}{c}W \times 10^{4} \\
\left(\Omega^{-1} \mathrm{~s}^{0.5} \mathrm{~cm}^{-2}\right)\end{array}$ & $\begin{array}{c}E I_{\mathrm{I}} \\
\%\end{array}$ \\
\hline 0 & 44.61 & 0.88 & 0.32 & 32.78 & 0.63 & 2.20 & 1.03 & \\
$1 \times 10^{-5}$ & 27.38 & 0.90 & 0.71 & 20.04 & 0.71 & 4.92 & 0.93 & 54.93 \\
$5 \times 10^{-5}$ & 21.17 & 0.91 & 0.87 & 16.11 & 0.74 & 6.53 & 0.85 & 63.22 \\
$1 \times 10^{-4}$ & 18.21 & 0.91 & 1.50 & 12.53 & 0.76 & 9.46 & 0.79 & 78.67 \\
$5 \times 10^{-4}$ & 14.50 & 0.93 & 3.11 & 10.67 & 0.78 & 14.17 & 0.77 & 89.71 \\
$1 \times 10^{-3}$ & 12.37 & 0.92 & 4.08 & 8.42 & 0.78 & 17.38 & 0.74 & 92.16 \\
\hline \hline
\end{tabular}


The semicircles in the high frequency region are generally associated with the relaxation of the electrical double-layer with their diameters representing the charge transfer resistance [38-41]. The smaller the charge transfer resistance, the faster the corrosion rate. The inhibition efficiency of caffeine $\left(I E_{\mathrm{I}} \%\right)$ for $\mathrm{Cu}$ electrode can be then calculated from the charge transfer resistance as follows:

$$
I E_{\mathrm{I}} \%=\frac{\left(R_{1}\right)_{\mathrm{inh}}-R_{1}}{\left(R_{1}\right)_{\mathrm{inh}}} \times 100
$$

where $R_{1}$ and $\left(R_{1}\right)_{\text {inh }}$ are the charge transfer resistance without and with inhibitor, respectively. The inhibition efficiency increases with the caffeine concentration and the inhibition efficiency up to $\approx$ $92 \%$ could be achieved in chloride solution (Table 2). The inhibition efficiency determined from the polarization and impedance measurements are consistent.

\subsection{Adsorption of caffeine}

Adsorption of caffeine on the $\mathrm{Cu}$ surface was further characterized by fitting the experimental data to several adsorption isotherms. The fractional surface coverage, $\theta$, at different concentrations of caffeine in $\mathrm{NaCl}$ solution, $c$, was determined from the corresponding polarization and impedance measurements according to:

$$
\theta=\frac{i_{\text {corr }}-\left(i_{\text {corr }}\right)_{\text {inh }}}{i_{\text {corr }}}
$$

$$
\theta=\frac{\left(R_{1}\right)_{\text {inh }}-R_{1}}{\left(R_{1}\right)_{\text {inh }}}
$$

The Langmuir adsorption isotherm (Equation 9) was found to most suitably describe the adsorption behaviour of caffeine on $\mathrm{Cu}$ :

$$
K c=\frac{\theta}{1-\theta}
$$

where $K$ is the equilibrium adsorption constant. The relation between the equilibrium adsorption constant and free energy of adsorption $\Delta G_{\text {ads }}^{\circ}$ is given by:

$$
K=\frac{1}{c_{\text {solvent }}} \exp \left(\frac{-\Delta G_{\text {ads }}^{\circ}}{R T}\right)
$$

where $c_{\text {solvent }}$ represents the molar concentration of the solvent, which in the case of water is $55.5 \mathrm{~mol}$ $1^{-1}, R$ is the universal gas constant, and $T$ is the absolute temperature. The Langmuir isotherm, Equation (9), could be rearranged into the following expression:

$$
\frac{c}{\theta}=\frac{1}{K}+c
$$

Accordingly, a linear relationship can be obtained when $c / \theta$ is plotted as a function of $c$, with a slope of unity. These plots are shown in Figure 7 and are linear with slopes of 1.08 and 1.07 for both polarization and impedance data, which suggests that the Langmuir adsorption isotherm is obeyed.

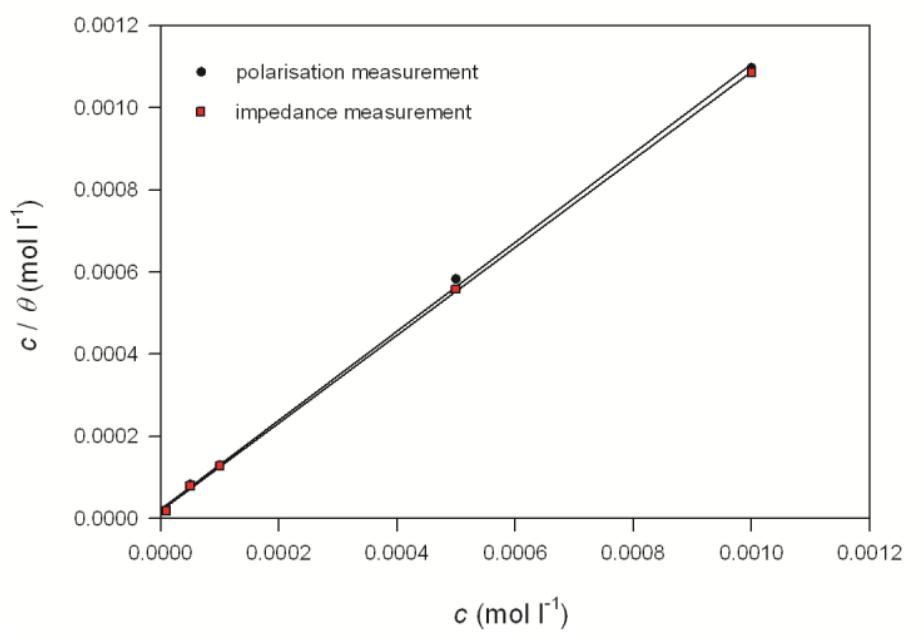

Fig. 7. The Langmuir adsorption isotherms of caffeine adsorption onto a $\mathrm{Cu}$ surface in $0.5 \mathrm{~mol} \mathrm{l}^{-1} \mathrm{NaCl}$ solution determined by polarization and impedance measurements 
The free energy of adsorption was calculated from polarization and impedance data and found to be equal to -36.54 and $-36.97 \mathrm{~kJ} \mathrm{~mol}^{-1}$, respectively. It is well known that values of $\Delta G_{\text {ads }}^{\circ}$ in the order of $-20 \mathrm{~kJ} \mathrm{~mol}^{-1}$ or lower indicate a physisorption, while those of order of $-40 \mathrm{~kJ} \mathrm{~mol}^{-1}$ or higher involve charge sharing or charge transfer from the inhibitor molecules to the metal surface to form a coordinate type of bond (chemisorption) $[42,43]$. The magnitude of $\Delta G_{\text {ads }}^{\circ}$ suggests a strong (possibly chemisorptive) interaction between caffeine and the $\mathrm{Cu}$ surface, which is in the line with the prediction of the Langmuir isotherm.

\subsection{Quantum chemical and molecular dynamics simulation studies}

A realistic route to study the complex processes occurring between adsorbed inhibiting spe- cies and metal surfaces at the molecular level involves computer simulations of suitable models. The density functional theory (DFT) has been used widely in this regard. Certain electronic structure parameters have been correlated with the effecttiveness of adsorption-type inhibitors. These include the energy of the highest occupied molecular orbital $\left(E_{\mathrm{HOMO}}\right)$, which is associated with the capacity of a molecule to donate electrons, the lowest unoccupied molecular orbital $\left(E_{\mathrm{LUMO}}\right)$ energy corresponding to a tendency for electron acceptance and the HOMO-LUMO energy gap. Others include charge densities, electronic energies, dipole moments, molecular surface area, etc. [44-48]. The geometry optimized structure, HOMO and LUMO orbitals, total electron density, as well as Fukui function for electrophilic $\left(f^{-}\right)$and nucleophilic $\left(f^{+}\right)$ attack of the caffeine molecule are presented in Figure 8.
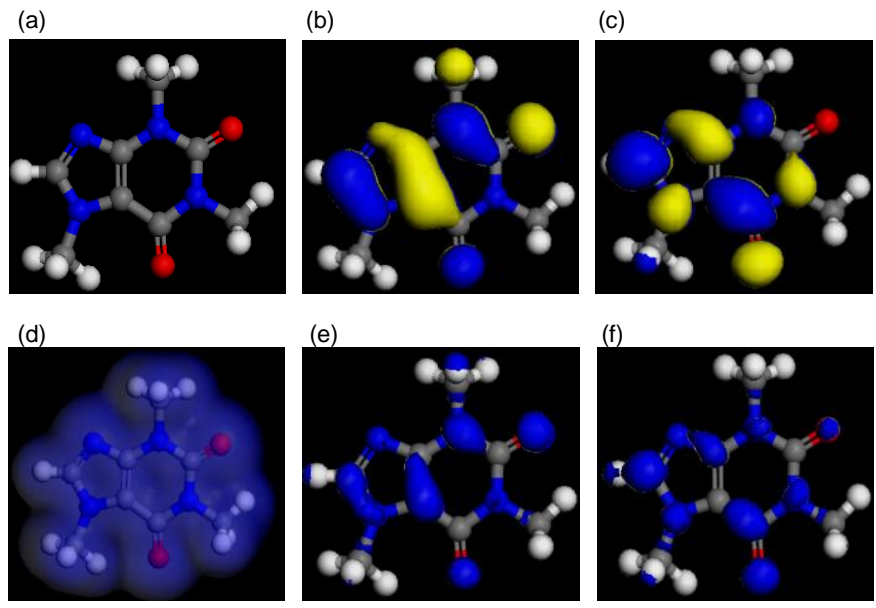

Fig. 8. Electronic properties of caffeine: (a) optimized structure, (b) HOMO orbital, (c) LUMO orbital,

(d) total electron density, (e) Fukui $f^{-}$function, (f) Fukui $f^{+}$function.

(Atom legend: white $=\mathrm{H}$; gray $=\mathrm{C}$; red $=\mathrm{O}$; blue $=\mathrm{N}$.)

The blue and yellow isosurfaces depict the electron density difference; the blue regions show electron accumulation, while the yellow regions show electron loss.

The HOMO and LUMO orbitals of caffeine are more or less spread over the xanthine nucleus, with the HOMO saturated more or less around the conjugated pi bond system, while the LUMO is localized around the individual heteroatoms. The electron density is spread all around the molecule; hence we should expect a flat-lying adsorption orientation. The local reactivity of the molecule was analyzed by means of the Fukui indices (FI) to assess reactive regions in terms of nucleophilic and electrophilic behaviour. The $f^{-}$measures reactivity with respect to electrophilic attack or the propensity of the molecule to release electrons, while $f^{+}$is a measure of reactivity relating to nucleophilic attack or tendency of the molecule to attract elec- trons. Our results show that the $f^{-}$sites correspond with the HOMO locations, while the $f^{+}$sites correspond with the LUMO locations; indicating the zones through which the molecule would likely interact with the $\mathrm{Cu}$ surface.

The tendency of a given molecule to be adsorbed on a metal surface depends on its electronic structure or molecular size, respectively giving rise to chemical deactivation of active corrosion sites or geometrical blocking. The former effect will be more pronounced if the functional groups in the molecule have a high tendency to donate electrons, as is often reflected by the $E_{\mathrm{HOMO}}$ and $E_{\mathrm{LUMO}}$ values. High values of $E_{\mathrm{HOMO}}$ indicate the disposition of the molecule to donate electrons to an appropri- 
ate acceptor with vacant molecular orbitals. Similarly, low values of the gap $\Delta E=E_{\mathrm{LUMO}}-E_{\mathrm{HOMO}}$ will render good inhibition efficiencies since the energy to remove an electron from the last occupied orbital will be minimized. The range of the obtained values of $E_{\text {Hомо }}(-5.513 \mathrm{eV}), E_{\mathrm{LUMO}}(-$ $1.947 \mathrm{eV})$ and $\Delta E(3.566 \mathrm{eV})$ suggest that the interaction of the caffeine molecule with the metal surface would be mostly noncovalent, but would rather proceed via noncovalent (physisorptive) interactions [49].

Molecular dynamics (MD) simulations were also undertaken to illustrate the adsorption of the caffeine molecule on the $\mathrm{Cu}$ surface at a molecular level. Figures $9 \mathrm{a}$ and $9 \mathrm{~b}$ show representative snapshots of the side view and top view of the lowest energy adsorption orientation for a single caffeine molecule on the $\mathrm{Cu}(110)$ surface from our simulations. The molecule can be seen to maintain a flatlying adsorption orientation on the $\mathrm{Cu}$ surface, as expected from the delocalization of the electron density all around the molecule. This orientation maximizes contact with the metal surface and, hence, augments the degree of surface coverage.
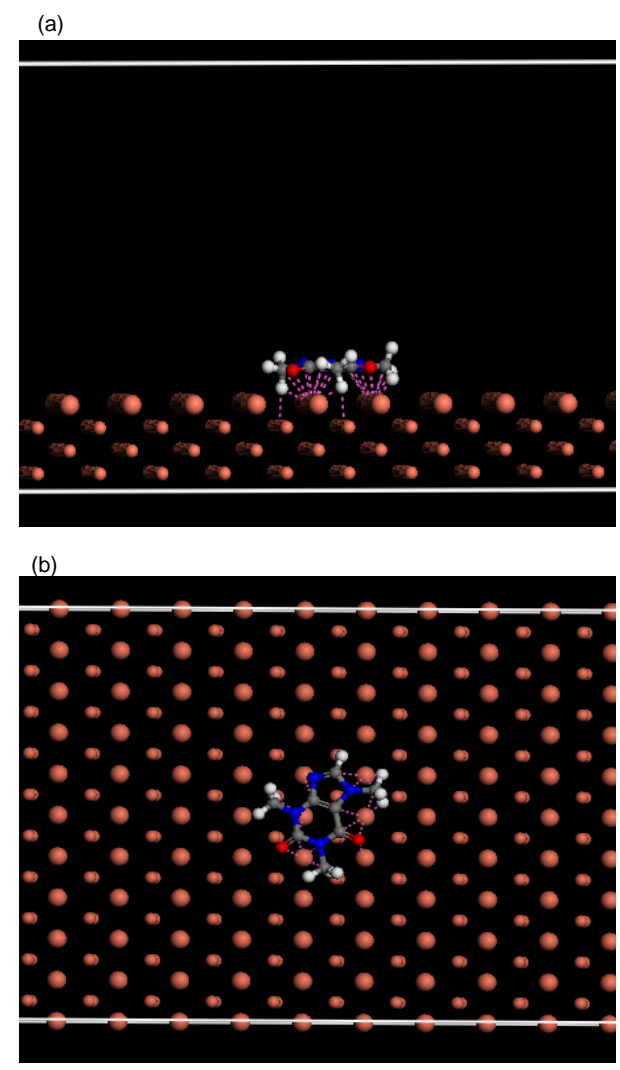

Fig. 9. Representative snapshots of the (a) side view and (b) on-top view of caffeine on the $\mathrm{Cu}(110)$ surface $(\mathrm{Cu}$ atoms on the surface plane are represented by the larger spheres on the $\mathrm{Cu}$ slab). The pink dotted lines depict close contact interactions between the molecule and the surface.
To quantitatively appraise the interaction between caffeine and the $\mathrm{Cu}$ surface, the adsorption energy $\left(E_{\text {ads }}\right)$ was calculated using the relationship in Equation (12):

$$
E_{\text {ads }}=E_{\text {total }}-\left(E_{\mathrm{Caf}}+E_{\mathrm{Cu}}\right) .
$$

A negative value of $E_{\text {ads }}$ corresponds to a stable adsorption structure whilst $E_{\mathrm{Caf}}, E_{\mathrm{Cu}}$ and $E_{\text {total }}$ correspond respectively to the total energies of the caffeine molecule, $\mathrm{Cu}(110)$ slab and the adsorbed caffeine/ $\mathrm{Cu}(110)$ couple in the gas phase. The total energies were calculated by averaging the energies of the five most stable representative adsorption configurations. The magnitude of our obtained $E_{\text {ads }}$ value of $-56.0 \mathrm{kcal} \mathrm{mol}^{-1}$ is, however, not in full agreement with the strong caffeine-Cu interaction as predicted experimentally from the $\Delta G_{\text {ads }}^{\circ}$ values.

Molecular dynamics simulations were also undertaken to assess the adsorption characteristics of a polymeric cluster of caffeine molecules, which will better mimic the actual situation within an adsorbed inhibitor layer. The polymeric cluster was generated from the caffeine molecule (repeat unit) using the Polymer Builder (MS Studio 4.0). The resulting polymer conformation (Figure 10a), which is somewhat unrealistic, was further modified using the Amorphous Cell module to generate chains containing sequences of backbone dihedrals typical of those found in actual melts or in ideal solutions [50-52].
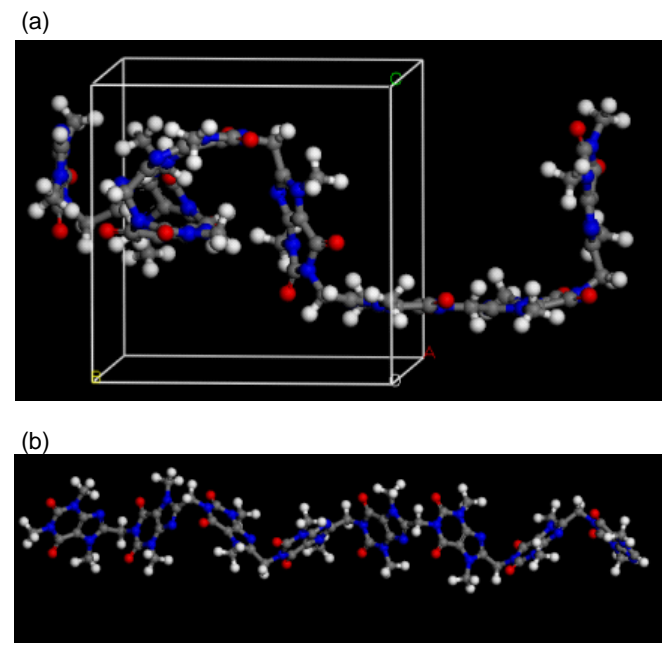

Fig. 10. Caffeine polymer

(a) initial and (b) optimized structure

The Amorphous Cell construction temperature was $303 \mathrm{~K}$, while the number of conforma- 
tions, number of molecules and target density within the confined layer were all unity. The lattice parameters were kept analogous to those of the $\mathrm{Cu}$ (110) slab. The reconstructed polymeric cluster of caffeine molecules (Figure 10b) was subsequently superimposed on the $\mathrm{Cu}(110)$ slab using the Layer Builder [53]. The $\mathrm{Cu}(110)$ slab was first built and relaxed by minimizing its energy via molecular mechanics using the Discover minimizer (MS Studio 4.0) [54]. The surface area was increased and its periodicity changed by constructing a $10 \times 10$ super cell with a vacuum slab of thickness $30 \AA$. The resulting layered structure (Figure 11) then contains the $\mathrm{Cu}(110)$ slab, the polymeric cluster of caffeine molecules and the vacuum.
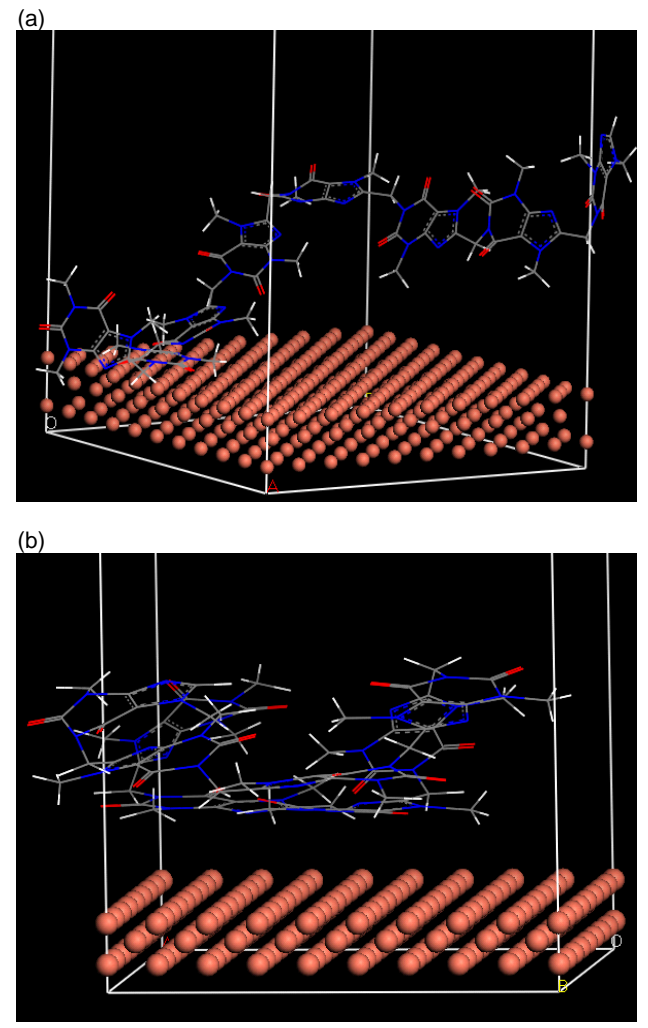

Fig. 11. Interaction of the polymeric cluster of caffeine with a $\mathrm{Cu}(110)$ slab

Quantitative appraisal of the interaction energy of the polymer and the surface was calculated as follows:

$$
E_{\text {interaction }}=E_{\text {total }}-\left(E_{\mathrm{Cu}}+E_{\text {polymer }}\right)
$$

$E_{\text {total }}$ is the energy of the surface and the polymer, $E_{\mathrm{Cu}}$ is the energy of the $\mathrm{Cu}$ surface without the polymer, $E_{\text {polymer }}$ is the energy of the polymer without the surface and the interaction energy
$E_{\text {interaction }}=-421.52 \mathrm{kcal} \mathrm{mol}^{-1}$. As expected, the interaction energy is enhanced by increasing the number of caffeine molecules on the $\mathrm{Cu}$ surface, with a value of $-421.52 \mathrm{kcal} \mathrm{mol}^{-1}$, which is in the range of chemisorptive interactions predicted by the $\Delta G_{\text {ads }}^{\circ}$ values. In other words, the polymeric cluster of caffeine molecules interacts more strongly with the $\mathrm{Cu}(110)$ surface than the single molecule. This could be related to the observed trend of rapidly increasing inhibition efficiency with increase in caffeine concentration and probably accounts for the high inhibition efficiency of caffeine as observed experimentally.

\section{CONCLUSIONS}

Caffeine was isolated from black tea, and characterization of the isolate by melting point determination, $R_{\mathrm{f}}$ value, IR and UV spectra confirmed the presence of high purity caffeine.

The inhibitive properties of caffeine towards the corrosion of copper in $\mathrm{NaCl}$ solution investtigated using the potentiodynamic polarization and EIS measurements established that the caffeine was a very good cathodic inhibitor, with an inhibition efficiency up to $\approx 92 \%$. The mechanism of the corrosion inhibition process is based on the adsorption of the caffeine on the active corrosion sites. The adsorption behaviour can be described by the Langmuir adsorption isotherm, and the value of the standard free adsorption energy of $\approx-37 \mathrm{~kJ} \mathrm{~mol}^{-1}$ indicates strong adsorption of the caffeine on the copper surface.

Molecular dynamics simulation of metalinhibitor interactions considered adsorption of a single caffeine molecule as well as a polymeric cluster of caffeine molecules on a $\mathrm{Cu}(110)$ slab. The magnitude of the obtained binding energies confirms that the polymeric cluster of caffeine molecules interacts more strongly with the $\mathrm{Cu}$ surface, implying that binding energy is enhanced by increasing the number of caffeine molecules on the $\mathrm{Cu}$ surface, in agreement with the experimental findings.

\section{REFERENCES}

[1] M. Pourbaix, Atlas of Electrochemical Equilibria in Aqueous Solutions, NACE International Cebelcor, Houston, 1974.

[2] H. H. Strehblow, B. Titze, The investigation of the passive behaviour of copper in weakly acid and alkaline solutions and the examination of the passive film by esca and ISS. Electrochim. Acta, 25, 839-850 (1980). 
[3] M. R. G. de Chialvo, R. C. Salvarezza, D. Vasquez Moll, A. J. Arvia, Kinetics of passivation and pitting corrosion of polycrystalline copper in borate buffer solutions containing sodium chloride. Electrochim. Acta, 30, 1501-1511 (1985).

[4] W. Qafsaoui, G. Mankowski, F. Dabosi, The pitting corrosion of pure and low alloyed copper in chloride containing borate buffered solutions. Corros. Sci., 34, 17-25 (1993).

[5] J. P. Duthil, G. Mankowski, A. Giusti, The synergetic effect of chloride and sulphate on pitting corrosion of copper. Corros. Sci., 38, 1839-1849 (1996).

[6] P. B. Raja, M. G. Sethuraman, Natural products as corrosion inhibitor for metals in corrosive media - A review. Matt. Lett., 62, 113-116 (2008).

[7] M. Sangeetha, S. Rajendran, T. S. Muthumegala, A. Krishnaveni, Green corrosion inhibitors - An overview. Mat. Prot., 52, 3-19 (2011).

[8] E. E. Oguzie, Corrosion inhibition of aluminium in acidic and alkaline media by Sansevieria trifasciata extract. Corros. Sci., 49, 1527-1539 (2007).

[9] M. Kliškić, J. Radošević, S. Gudić, V. Katalinić, Aqueous extract of Rosmarinus offinalis L. as inhibitor of Al-Mg alloy corrosion in chloride solution. J. Appl. Electrochem., 30, 823-830 (2000).

[10] J. S. Chauhan, Anticorrosion behaviour of Zenthoxylum alatum extract in acidic media. Asian J. Chem., 21, 1975-1978 (2009).

[11] H. H. Rehan, Corrosion control by water-soluble extracts from leaves of economic plants. Materialwiss. Werkst., 34, 232-237 (2003).

[12] M. A. Quraishi, A. Singh, V. K. Singh, D. K. Yadav, A. K. Singh, Green approach to corrosion inhibition of mild steel in hydrochloric acid and sulphuric acid solutions by the extract of Murraya koenigii leaves. Mat. Chem. Phys., 122, 114-122 (2010).

[13] A. Y. El-Etre, M. Abdallah, Z. E. El-Tantawy, Corrosion inhibition of some metals using lawsonia extract. Corros. Sci., 47, 385-395 (2005).

[14] A. Finger, S. Kuhr, U. H. Engelhardt, Chromatography of tea constituents, J. Chromatogr. A, 624, 293-315 (1992).

[15] P. L. Fernández, M. J. Martín, A. G. González, F. Pablos, HPLC determination of catechins and caffeine in tea. Differentiation of green, black and instant teas. Analyst, 125, 421-425 (2000).

[16] A. Mumin, K. F. Akhter, Z. Abedin, Z. Hossain, Determination and characterization of caffeine in tea, coffee and soft drinks by solid phase extraction and high performance liquid chromatography (SPE-HPLC), Malaysian J. Chem., 8, 45-51 (2006).

[17] M. Guru, H. Icen, Obtaining of caffeine from Turkish tea fiber and stalk wastes. Bioresource Technol., 94, 1719 (2004).

[18] A. Smith, Effect of caffeine on human behaviour. Food Chem. Toxicol., 40, 1243-1255 (2002).

[19] M. J. Glade, Caffeine - not just a stimulant. Nutrition, 26, 932-938 (2010).
[20] N. Anthony, E. Malarvizhi, P. Maheshwari, S. Rajendran, N. Palaniswamy, Corrosion inhibition by caffeine $-\mathrm{Mn}^{2+}$ system. Indian J. Chem. Technol., 11, 346-350 (2004).

[21] S. Rajendran, A. J. Amalraj, M. J. Joice, N. Anthony, D. C. Trivedi, M. Sundaravadivelu, Corrosion inhibition by the caffeine $-\mathrm{Zn}^{2+}$ system. Corros. Rev., 22, 233-248 (2004).

[22] T. Fallavena, M. Antonow, R. S. Goncalves, Caffeine as non-toxic corrosion inhibitor for copper in aqueous solutions of potassium nitrate. Appl. Surf. Sci., 253, 566-571 (2006).

[23] L. G. de Trindade, R. S. Goncalves, Evidence of caffeine adsorption on a low-carbon steel surface in ethanol. Corros. Sci., 51, 1578-1583 (2009).

[24] B. J. Delley, An all-electron numerical method for solving the local density functional for polyatomic molecules. J. Chem. Phys., 92, 508-517 (1990).

[25] B. J. Delley, From molecules to solids with the $\mathrm{Dmol}^{3}$ approach. J. Chem. Phys., 113, 7756-7764 (2000).

[26] C. J. Casewit, K. S. Colwell, A. K. Rappé, Application of universal force field to organic molecules. J. Am. Chem. Soc., 114, 10035-10046 (1992).

[27] C. J. Casewit, K. S. Colwell, A. K. Rappé, Application of universal force field to main group elements. J. Am. Chem. Soc., 114, 10046-10053 (1992).

[28] H. V. Aeschbacher, J. Atkinson, B. Domahidy, The effect of caffeine on barbiturate sleeping time and brain level. J. Pharmacol. Exp. Ther., 192, 635-641 (1975).

[29] K. Venkata Sowmya, K. Ravishankar, D. Peer Basha, G.V.N. Kiranmayi, Estimation of caffeine and sodium benzoate in caffeine and sodium benzoate injection by isoabsorption method (isobestic method). IJPCBS, 1, 26-31 (2011).

[30] O. E. Barcia, O. R. Mattos, N. Pebere, B. Tribollet, Mass-transport study for the electrodissolution of copper in $1 \mathrm{M}$ hydrochloric acid solution by impedance. J. Electrochem. Soc., 140, 2825-2832 (1993).

[31] A. L. Bacarella, J. C. Griess, The anodic dissolution of copper in flowing sodium chloride solutions between $25^{\circ}$ and $175^{\circ}$ C. J. Electrochem. Soc., 120, 459-465 (1973).

[32] F. K. Crundwell, The anodic dissolution of copper in hydrochloric acid solutions. Electrochim. Acta, 37, 2707-2714 (1992).

[33] H. P. Lee, K. Nobe, Kinetics and mechanisms of $\mathrm{Cu}$ electrodissolution in chloride media. J. Electrochem. Soc., 133, 2035-2043 (1986).

[34] C. Deslouis, B. Tribollet, G. Mengoli, M. M. Musiani, Electrochemical behaviour of copper in neutral aerated chloride solution. I. Steady-state investigation. J. Appl. Electrochem., 18, 374-383 (1988).

[35] H. Otmačić, E. Stupnišek-Lisac, Copper corrosion inhibitors in near neutral media, Electrochim. Acta. 48, 985-991 (2003).

[36] G. Kear, B.D. Barker, F. C. Walsh, Electrochemical corrosion of unalloyed copper in chloride media - A critical review. Corros. Sci., 46, 109-135 (2004). 
[37] I. D. Raistrick, D. R. Franceschetti J. R. Macdonald, Theory, in: Impedance Spectroscopy, E. Barsoukov, J. R. Macdonald (Eds.), J. Wiley \& Sons, Inc., New Jersey, 2005, pp. 27-128.

[38] H. Ma, S. Chen, L. Niu, S. Zhao, S. Li, Inhibition of copper corrosion by several Schiff bases in aerated halide solutions. J. Appl. Electrochem., 32, 65-72 (2002).

[39] E. Sherif, S.-M. Park, Inhibition of copper corrosion in $3.0 \% \mathrm{NaCl}$ solution by $\mathrm{N}$-Phenyl-1,4-phenylenediamine. J. Electrochem. Soc., 152, B428-B433 (2005).

[40] E. Sherif, S.-M. Park, Inhibition of copper corrosion in acidic pickling solutions by $N$-phenyl-1,4-phenylenediamine. Electrochim. Acta, 51, 4665-4673 (2006).

[41] K. F. Khaled, Guanidine derivative as a new corrosion inhibitor for copper in $3 \% \mathrm{NaCl}$ solution. Mater. Chem. Phys., 112, 104-111 (2008).

[42] F. M. Donahue, K. Nobe, Theory of organic corrosion inhibitors: Adsorption and linear free energy relationships. J. Electrochem. Soc., 112, 886-891 (1965).

[43] E. Khamis, F. Belluci, R. M. Latanision, E.S.H. ElAshry, Acid corrosion inhibition of nickel by 2-(triphenosphoranylidene) succinic anhydride. Corrosion, 47, 677-686 (1991).

[44] S. Martinez, I. S. Stagljar, Correlation between the molecular structure and the corrosion inhibition efficiency of chestnut tannin in acidic solutions. THEOCHEM, 640, 167 (2003).

[45] D. Turcio-Ortega, T. Pandiyan, J. Cruz, E. GarciaOchoa, Interaction of imidazoline compounds as a model for corrosion inhibition: DFT and electrochemical studies. J. Phys. Chem. C, 111, 9853-9866 (2007).
[46] G. Gece, The use of quantum chemical methods in corrosion inhibitor studies. Corros. Sci., 50, 2981-2992 (2008).

[47] I. B. Obot, N.O. Obi-Egbedi, Adsorption properties and inhibition of mild steel corrosion in sulphuric acid solution by ketoconazole: Experimental and theoretical investigation. Corros. Sci., 52, 198-204 (2010).

[48] K. F. Khaled, Molecular simulation, quantum chemical calculations and electrochemical studies for inhibition of mild steel by triazoles. Electrochim. Acta, 53, 34843492 (2008).

[49] E. E. Oguzie, Y. Li, S. G. Wang, F. H. Wang, Understanding corrosion inhibition mechanisms - experimental and theoretical approach. RSC Advances, 1, 866-873 (2011).

[50] I. Bitsanis, J. J. Magda, M. Tirrell, H. T. Davis, Molecular dynamics of flow in micropores. J. Chem. Phys., 87, 1733-1750 (1987).

[51] R. Khare, J. J. de Pablo, A. Yethiraj, Rheology of confined polymer melts. Macromolecules, 29, 7910-7918 (1996).

[52] S. A. Gupta, H. D. Cochran, P. T. Cummings, Shear behavior of squalane and tetracosane under extreme confinement. I. Model, simulation method, and interfacial slip. J. Chem. Phys., 107, 10316-10326 (1997).

[53] M. P. Allen, D. J. Tildesley, Computer Simulation of Liquids, Oxford University Press, London, 1987.

[54] D. Hofmann, L. Fritz, J. Ulbrich, C. Schepers, M. Boehning, Detailed-atomistic molecular modeling of small molecule diffusion and solution processes in polymeric membrane material. Macromol. Theory Simul., 9, 293-327 (2000). 
